\title{
Impact of wild geese on grasslands in the Netherlands
}

G. W. T. A. Groot Bruinderink, Centre for Agrobiological Research (CABO), P.O. Box 14, NL 6700 AA Wageningen, Netherlands

Received 26 January 1988; accepted 30 March 1988

\begin{abstract}
The impact of a combination of grazing, treading, and manuring by wintering gees on Lolium swards was studied during three winters from 1983 to 1985 in the Dutch province of Friesland. The implications for dairy farming were analysed.
\end{abstract}

Key words: grazing, Lolium swards, migratory geese, management

Introduction. Over the past twenty years, numbers of migratory geese wintering in the Netherlands increased from about 100000 in the 1960 s to 600000 in the winter of 1983-84. The most common species are the white-fronted goose, the greylag goose, the bean goose, the pink-footed goose, the barnacle goose and the Brent goose. The northern province of Friesland receives almost $60 \%$ of all these geese for a longer period each year (Ganzenwerkgroep Nederland, annual reports 19761983). Along with this increase in numbers of geese, there was a steady rise of numbers of farmers, especially dairy farmers, complaining about damage to their crops as a result of grazing by geese. The amount paid by the Game Fund to compensate for these yield losses increased from $f 6000$ in 1974 to $f 1500000$ in 1984 .

Farmers are using higher rates of chemical fertilizers, in particular nitrogen. They have reseeded more grassland with Lolium perenne and have improved drainage. These and other changes in grassland utilization have shortened the non-productive winter period and mean that wild geese compete with an ever-increasing number of dairy cows ('t Mannetje, 1985). In order to find a method of assessing the impact of grazing, treading and manuring of wild geese on grassland, in particular Lolium swards, characteristics of grassland were measured during three winter in the Province of Friesland by the Centre for Agrobiological Research (CABO). Two winters were mild (1982/83 and 1983/84) and one was hard (1984/85).

Material and methods. The experimental design was based on the split-plot principle, each plot consisting of three grazed $(\mathrm{g})$ and three ungrazed $(\mathrm{u})$ fields of $2 \times 5$ $\mathrm{m}^{2}$ each, named after the time they were harvested: $\mathrm{T}_{1}$ fields (April 26), $\mathrm{T}_{2}$ fields (first week of May) and $\mathrm{T}_{3}$ fields (mid-May). The ungrazed areas were protected by thin poles and wires which gave no cage effect. Effects of grazing, treading, and manuring by wild geese were measured by comparing the following quantities:

- dry matter yield at harvest time,

- mass fraction of dry matter of each species in herbage,

- number of species in sward per unit area, 
- number of tillers in sward per unit area,

- substance content of nutrient element (N, P or K) in dried soil,

- permeability of soil,

- load-bearing capacity of soil,

- moisture tension,

- content of net energy in sward,

- yield of net energy for milk production,

- digestibility of organic matter in vitro.

Results. Yield losses were restricted to the first cut. Mean values of differences in sward height at end of grazing and yield losses are shown in Table 1. Multifactorial analysis showed that about two-thirds of the variance in yield loss in the three years $(n=156)$ could be attributed to the three factors. In the units indicated, numeric values were related $(P=0.001)$ by Equation 1 :

$$
L=55.656-21.13 x_{1}+0.1756 x_{2}-0.1623 x_{3}{ }^{*}
$$

where:

$$
\begin{gathered}
\begin{aligned}
L= & \text { yield loss in dry matter of first cut }\left(\mathrm{g} \mathrm{m}^{-2}\right)^{*} \\
= & Y_{\mathrm{u}}-Y_{\mathrm{g}} \\
& \text { where: } Y=\text { yield of dry matter }\left(\mathrm{g} \mathrm{m}^{-2}\right)^{*}
\end{aligned} \\
\begin{aligned}
& x_{1}= \text { difference in sward height at end of grazing }(\mathrm{cm}) \\
&= h_{\mathrm{u}}-h_{\mathrm{g}} \\
& \text { where: } h=\text { height of sward }(\mathrm{cm}) \\
& \mathrm{g}=\text { grazed sward } \\
& \mathrm{u}=\text { ungrazed sward }
\end{aligned} \\
\begin{aligned}
& x_{2}= Y_{\mathrm{u}}\left(\mathrm{g} \mathrm{m}^{-2}\right)^{*} \\
& x_{3}= \text { temperature sum from last grazing to harvest }\left({ }^{\circ} \mathrm{C} \mathrm{d}\right) \\
&= \int\left(T-T_{\mathrm{o}}\right) \mathrm{d} t \\
& \text { where: } T=\text { temperature }\left({ }^{\circ} \mathrm{C}\right) \\
& T_{\mathrm{o}}=0{ }^{\circ} \mathrm{C} \\
& t=\text { time }(\mathrm{d})
\end{aligned}
\end{gathered}
$$

In general, a mild winter increases yield losses. In hard winters, all aerial parts are frozen and the leaf area index is practically zero for both grazed and ungrazed sward at the start of spring growth.

After two winters of grazing, mass fraction of dry matter from weeds in grazed plots was more than in ungrazed plots: the plots became weedier. Grazing had no

* With the unit $\mathrm{kg}$ are $^{-1}$ instead of $\mathrm{g} \mathrm{m}^{-2}$, the equation was: $L=5.5656-2.113\left(x_{1}\right)+0.1756\left(x_{2}\right)-$ $0.01623\left(x_{3}\right)$. (In: G. W. T. A. Groot Bruinderink, 1987. Wilde ganzen en cultuurgrasland in Nederland (Wild geese and grasslands in the Netherlands). CABO-publication $\mathrm{Nr}$ 422. CABO, Wageningen. 
Table 1 . Mean differences in sward-height $\left(x_{1}\right)$ and mean yield loss $(L)$ caused by grazing. SE in parenthesis. $n=156$.

\begin{tabular}{lllr}
\hline Year & Groups of fields & $x_{1}(\mathrm{~cm})$ & $L\left(\mathrm{~g} \mathrm{~m}^{-2}\right)$ \\
1 & T1 & $2.08(0.92)$ & $90.9(44.5)$ \\
2 & T2 & $2.24(1.02)$ & $110.7(74.6)$ \\
& T1 & $1.34(0.59)$ & $77.9(43.6)$ \\
& T2 & $1.30(0.74)$ & $89.7(41.6)$ \\
3 & T3 & $1.28(0.78)$ & $84.6(72.2)$ \\
& T1 & $1.17(0.64)$ & $37.6(28.0)$ \\
& T2 & $1.06(0.78)$ & $45.1(48.6)$ \\
& T3 & $1.24(0.86)$ & $33.5(49.4)$ \\
\hline
\end{tabular}

effect on number of species in the sward nor on number of tillers. Droppings had no effect as fertilizer $(\mathrm{N}, \mathrm{P}, \mathrm{K})$. Treading by geese did not alter permeability, loadbearing capacity nor moisture tension of the surface soil. Grazing by geese improved the quality (energy content) but decreased the yield of energy at the first cut. Digestibility of herbage was not affected.

Implications for nature management. Equation 1 allows assessment of the impact of grazing by geese on herbage production. The yield losses correspond to a retardation in spring growth of $7.1,5.5$, and 2.4 days for 1983, 1984, and 1985, respectively.

This retardation can be reduced by application of nitrogen in early spring, e.g. at a temperature sum of about $180^{\circ} \mathrm{C} d$ in a small overdose compared to normal, thus contributing to the integration of nature management with modern dairy farming.

\section{References}

Ganzenwerkgroep Nederland. Annual reports 1976-1983 Watervogels 1 (4), 2 (3), 3 (3), 4 (2), 5 (2) and 6(3). Limosa 56(1) and $57(1,1$ and 4).

Mannetje, L. 't, 1985. Intensivering van de graslandproductie in Nederland sinds de jaren vifftig en onderwerpen van verder onderzoek. Meststoffen 2: 3-7.

This synopsis is based on a Ph.D. Thesis 'Wilde ganzen en cultuurgrasland in Nederland' (Wild geese and grassland in the Netherlands) by G. W. T. A. Groot-Bruinderink. Centre for Agrobiological Research (CABO), Wageningen, Publication 422, 1987, 205 pp., 37 figs., 66 tables, 2 appendices, Dutch. Available as paper copy (order R084P, $f 20$ including postage) at NARD, clo Pudoc, P.O. Box 4, $6700 \mathrm{AA} W \mathrm{~W}$ geningen (telex $45015 \mathrm{blhwg}$ ). 